\title{
Policy making in interesting times: the Housing Finance and Policy Review, 1975-77
}

\author{
Peter Malpass* \\ University of the West of England
}

\begin{abstract}
This article starts from the observation that policy making is a relatively neglected area of research in housing studies, and argues that past events provide a useful way of investigating policy processes about which the actors are now freer to talk and the official files are accessible. The article reports research on the housing finance and policy review of 1975-77 and seeks to draw out some lessons of relevance to understanding policy making today.
\end{abstract}

Keywords: housing finance review, policy working, housing policy review.

\section{Policy making in interesting times: the Housing Finance and Policy Review,} 1975-77

In recent years the Westminster government has issued a series of housing policy statements and reviews, and commissioned a lot of research on the evaluation of various initiatives. One result is that we now have a lot of policy based evidence, if not evidence based policy. Despite the substantial proportion of housing research devoted to aspects of policy, one of the less well developed areas of housing studies remains the policy making process itself.

One way of getting at the policy making process is to go back to events long enough ago for the participants to be willing to talk freely, and for the official files to be open to scrutiny. This article therefore focuses on the major review of housing finance and housing policy in the mid-1970s, drawing on new research at the National Archives (TNA) and interviews in February and March 2007 with six of those who were actively involved in the review process at various stages between 1975 and 1977. As well as shedding light on the process of the review the article aims to draw out some conclusions of contemporary significance. 


\section{The background to the Housing Finance Review}

The claim that the housing finance review amounted to policy making in interesting times rests of the broad consensus in the academic literature about the significance of the 1970 s as a decade of crisis and change, of transition from the postwar settlement to a new, more open and market driven era. First, on the international level, in 1971 the Bretton Woods agreement on exchange rates collapsed after nearly thirty years, then in 1973-74 the world price of oil quadrupled, and then doubled again by 1976 , creating unprecedented balance of payments problems for all importing countries (Pollard, 1983: 287). In Britain inflation rose to the highest recorded levels in 1975, and in the second half of the decade unemployment also rose, to double the rate in 1969. In this context public expenditure came under the closest scrutiny, especially in the wake of the package of measures negotiated with the International Monetary Fund after the 1975 economic crisis (Cairncross, 1992: ch 5). Capital expenditure on housing was particularly hard hit in the late 1970 s and beyond. Keynesian policies of economic management were abandoned and there was debate about whether capitalism itself was in crisis. All this meant big challenges for the welfare state, which also generated talk of crisis, and the mid-1970s has been widely adopted as a turning point in the postwar welfare state (Lowe, 1993: 301, Malpass, 2005). Meanwhile, British politics had been polarised by aggressive anti-trade union legislation (the Industrial Relations Act, 1971), and by the declaration of a three day working week at the end of 1973 in response to industrial action by the miners, followed by a general election in February 1974, fought on the question of who governs Britain? A degree of harmony was restored under the Labour government's 'social contract' with the trades unions, but industrial action was again prominent in the so-called winter of discontent, 1978-9, contributing to the outcome of the general election of May 1979.

The 1970s was a decade of transition and change in British housing policy (Malpass and Murie, 1999, Malpass, 2005, Ginsburg, 1999). It began and ended with radical measures proposed by Conservative governments, first on rents and subsidies and then on the sale of council houses. Sandwiched between these high profile developments was the review of housing finance, later broadened into a review of housing policy as a whole, and carried out under the Labour government of 1974-79. The outcome was published as a green paper, together with supporting technical volumes (DoE, 1977). The review was the first major exercise of its kind since the Royal Commission on the Housing of the Working Classes in 1884-85 (Harloe, 1978: 4).

High levels of new building by local authorities in the twenty five years after 1945 resulted in a growing subsidy burden. In the owner occupier sector buyers could claim tax relief on mortgage interest at their marginal tax rate. As tax thresholds fell and the popularity of owner occupation grew after the Second World War the numbers of beneficiaries increased significantly. The outcome of these various measures was, first, that the majority of consumers paid less than the full economic cost of housing, and, second, that financial assistance was not distributed in a way that reflected individual need. Both were seen as arguments for reform.

In the late 1960s there was a build-up of pressure for change to the established set of conventions governing local authority rents and subsidies (Malpass, 1990). The problem was that there was no general principle for setting rents; each local authority had the freedom to set its rents so long as they could be defended as 'reasonable' (Parker, 1967). It was argued that subsidy was unrelated to actual current needs, and that while some local authorities were getting more than they needed to balance their books, others were getting less. Similarly some tenants were benefiting from subsidy even though they were capable of paying more, and some were being required to pay 
more than they could reasonably afford. In the private rented sector, some tenants were subject to controlled rents, others had 'fair rents' set by a rent officer (a state official), and the rest paid rents set by the market. The Labour government of the late 1960s had resisted demands for a municipal system based on current values, but the new Conservative government elected in June 1970 outlined proposals in a white paper entitled Fair Deal for Housing (DoE, 1971). This proposed that the fair rent system should be extended across the whole of the stock of rented housing, public and private.

No reform was proposed for the owner occupier sector (which had just passed 50 per cent of the entire stock), despite the arguments of those who pointed to the highly unfair way in which the benefits of mortgage interest tax relief (MITR) were distributed. At that time the Treasury refused to acknowledge that tax relief was a subsidy. However, Britain then experienced its first serious house price boom, when prices rose by 37 per cent in 1972 and 32\% in '73 (Boleat, 1982: 103-4), an event that focused public debate on what drove house prices and brought the question of tax relief into play.

The 1971 white paper was followed by legislation, the Housing Finance Act, 1972, which broke with established practice by withdrawing subsidies promised by previous governments, and introduced the requirement that all local authorities should both set fair rents for all their houses and then raise rents in prescribed stages towards those new rent levels. This proved to be highly controversial, both because of the 25 per cent (on average) rent increases required and because the Act removed the historic and cherished freedom of local councillors to set the rents for municipal tenants. It must be remembered that at that time local government was a more powerful force in policy and politics than is the case today. Councils then owned 29 per cent of all homes in England and Wales, and the Act was seen as an attack on the autonomy of local government, as well as the pockets of tenants. Nevertheless, the Act was also capable of being defended as an attempt to establish a coherent system for pricing rented housing across the public and private sectors, based on current values and incomes rather than historic costs.

In the febrile political atmosphere of late 1973 and early 1974 theoretical rectitude was not enough and the Labour Party in opposition committed itself to repealing the contentious parts of the 1972 Act. When Harold Wilson returned to Downing Street at the head of a minority government in early March 1974 anti-inflation powers were used to cancel rent increases due on 1 April. Later a Bill was introduced to repeal parts of the Act and to substitute a provisional subsidy system, pending the formulation of a new, more permanent system. The problem was that the Labour Party in opposition had committed itself to repealing the 1972 Act, but without having any clear idea of what to put in its place, apart from a temporary return to the status quo ante. The Secretary of State for the Environment, Anthony Crosland, announced that he was setting up

A searching and far-reaching inquiry into housing finance. The aim is to get back to fundamentals, to get beyond a housing policy of 'ad hoc-ery' and crisis management, and to find out precisely what needs to be done if we are to get on top of this desperate social problem once and for all (House of Commons Debates, vol 881, November 1974, col. 914).

Crosland is quoted as describing housing finance as 'a dog's breakfast' (Kilroy, 1984) and 'whimsical in the extreme' (Harloe, 1978: 4). In pursuit of a better system the review was given the following terms of reference: 
p. 68. Policy Making in Interesting Times: The Housing Finance and Policy Review, 1975-77

To review the arrangements for finance for the provision of housing and the assistance, direct and indirect, given from public funds; to consider what changes are desirable to facilitate adequate, timely and economical provision to meet differing needs with reasonable freedom of choice, and to secure a more equitable and balanced distribution of assistance; and to make recommendations (DoE, 1977: 133).

These terms of reference were later broadened to cover social aspects of housing policy. A number of key areas were never included: land supply for house building, the location of new development, and the organisation of the house building industry; private renting was given scant attention since there was a separate review of the Rent Acts under way at the time. There was also a separate review of local government finance under way, chaired by Frank Layfield. It was clearly not an exercise in joined-up government.

\section{The conduct of the review}

The review was conducted internally, within the Department of the Environment (DoE) (a separate review was carried in Scotland at the same time, but is not covered here). It has been suggested that an internal review was the price paid for terms of reference reaching beyond the public sector (Kilroy, 1978). It was carried out by a group of specially appointed economists, led by Professor Christopher Foster, on secondment from the LSE, working alongside a team of civil servants. Between May 1975 and July 197621 people were involved in writing over 100 papers providing background and analysis, sometimes running to 100 pages in length. The review team worked on a range of 'analytical descriptions' but given the immediate background to the review it was not surprising that attention came to focus on the problem of how to design a system that was fair and equitable to people in different housing tenures.

The provision or withholding of assistance is the chief method by which Government influences the operation of the housing system; and the structure of housing assistance (subsidy and tax relief) must be a central feature of the work of the Review (TNA, HLG 118/2559, note by secretary of the Advisory Group, 1975).

Equity between the two main tenures - public rented housing and owner occupation - is the issue on which the main debate on equity and housing finance is centred (TNA, HLG 118/2563, January 1977).

Although there was no invitation to do so, a number of interested outside bodies submitted evidence. The outcome was the production of a 'prodigious volume of paper' (TNA, CAB 184/295, letter from Goulding to Odling-Smee (both of CPRS) 6 Nov 1975). The review was guided by an inter-departmental Steering Group of officials, chaired by a deputy secretary in the DoE. In addition there was an Advisory Group, consisting mainly of representatives of local government and academics. Advisory Group meetings were chaired by the Secretary of State himself, but the group was kept at arm's length, and was never shown or invited to debate actual policy options (interview with M Harloe, March 2007). The two groups met regularly (but separately) during 1975 and less frequently up to at least the middle of 1976. By the late summer of 1976 the specialist advisors had left, the finance review had been widened into a policy review, and the team working on it had narrowed to four key people, permanent civil servants, whose task was to write the green paper (and the accompanying three technical volumes). 
The initial timescale for the review had envisaged completion within a year, followed by implementation in the second year (C Whitehead interview, February 2007). Accounts of the review refer to the loss of momentum resulting from Crosland's move to the Foreign Office in April 1976 (in the cabinet reshuffle following Wilson's resignation and James Callaghan's election as party leader and prime minister) but it is clear that significant slippage had already built up. Crosland's successor, Peter Shore, is usually depicted as less interested in and committed to radical reform, and it has been said that, irrespective of his own views, in the very difficult political and economic circumstances, Shore had little choice but to let the review run on (Kilroy, 1978: 9, Harloe, 1978: 6). However, Crosland's own style of working was one of the reasons that the review process took much longer than originally planned. Several interviewees referred to Crosland's preference for concentrating on one big issue at a time, and in 1975 it was to transport, not housing, that he devoted much of his attention. Crosland also expected very thorough briefing and analysis before applying himself to producing policy (Foster, 2005: 81).

It is accepted by those involved that the review lacked political leadership during the important first year. By the end of 1975 interested parties within the Central Policy Review Staff (CPRS) and Treasury were complaining about the lack of clarity and progress (TNA, CAB, 184/295, Goulding to Odling-Smee, 6 November 1975). (The CPRS, based in Downing Street, had been set up by Edward Heath in 1970 in response to the Fulton Report on the civil service, 1968. It was an in-house think-tank, designed to improve policy making by enabling more rational and strategic decision making, overcoming departmentalism and the cult of the generalist civil servant.) It was also argued that the DoE was reluctant to discuss fundamental principles and objectives. This view was not necessarily shared by those actually working on the review (Whitehead interview), and it is clear from the files that the team were working on and writing papers about fundamental principles. Nevertheless, the impression persisted that the DoE did not want to talk principles, and an explanation may lie in differences between the professional economists and the senior permanent civil servants (C Foster interview, March 2007, David Lipsey interview, March 2007). Certain senior civil servants were apparently unwilling to countenance major change, and adopted delaying tactics. This also emerges to some extent from the files. For example, the Treasury believed that proposals circulated to the Steering Group assumed that ministers should not be given even one option to show how they might substantially reduce public sector housing subsidies (TNA, CAB 184/295, Treasury note 25 November 1975). When pressed, the DoE produced what was called a 'sketch plan' in December 1975, a plan that was sharply criticised by the CPRS:

It typifies what is wrong with the DoE's present approach - it is bland, nonspecific and random in its selection of options...After all the analytical work which is supposed to have gone on, it really is a bit steep that at this stage of the Review the DoE should simply assume that pooled historic costs is the best way of fixing local authority rents, or that reduced mortgage interest relief is the best way of tackling subsidies in the owner occupier sector, without any discussion of alternative methods (TNA, CAB 184/295, Goulding to Ross 15 December 1975).

The Treasury view was that at the Steering Group meeting to discuss the sketch plan, the DoE had been 'most reluctant' to produce a paper setting out where the review had got to (TNA, CAB 184/295 Cousins to Baldwin, 7 January 1976). A little later at a one day inter-departmental conference to discuss local authority subsidies, 'the DoE were very defensive and tended to treat every query...as an attack' (TNA, CAB 184/295, Odling-Smee to Goulding 3 February 1976). 
Meanwhile, the CPRS had been working on its own proposals for reform, which it shared with the Treasury. Indeed it was proposed that the CPRS and Treasury should form a united front for housing finance review purposes, anticipating opposition form the DoE and Inland Revenue (TNA, CAB 184/295, Goulding to Sir K Berrill, 5 December 1975). The CPRS and Treasury shared the view that British households generally paid too little for their housing, and that reform should be based on economic pricing, albeit that progress towards this objective needed to be gradual. The DoE was said to accept the argument that subsidies in the local authority sector had become too high and needed to be reduced over time (TNA, CAB 184/295, note of a meeting between Treasury and DoE officials, 26 November 1975). But the Department was not ready to accept or move towards the sort of market based tenure neutral model advanced by the CPRS. By early November 1975 the CPRS had a draft of a proposal for reform based on economic pricing and targeted, means tested, assistance for those unable to afford higher costs (TNA, CAB 184/295, 3 November 1975).

It seems that Crosland was on the brink of returning his attention to housing when he was re-shuffled into a different post. Questions then arose as to whether to abandon or complete the review (Alan Holmans interview, February 2007), but in due course the decision was taken to press ahead as quickly as possible. As already mentioned, by the late summer of 1976 the review team had come down to four permanent civil servants, led by Terry Heiser (then an under secretary, later permanent secretary, DoE), who together drafted the final document. The pace was increased, reflecting not just the need finally to deliver something but also the change of senior administrative personnel. By September 1976 a draft paper on a possible new subsidy system for local authority housing was available for discussion, and by December Heiser could set out a possible timetable for the remaining stages leading up to publication, which he then pencilled in for 31 March 1977 (TNA, HLG 118/2563).

In practice a first draft green paper was ready by January 1977 (TNA, HLG 118/2563). It then had to be scrutinised by a cabinet committee, chaired by Lord Elwyn-Jones (the Lord Chancellor); a final draft was substantially complete by April (Holmans interview, 2007) for consideration by the full cabinet before publication in June. During the drafting process the Treasury had been kept at a distance, although there was informal contact between officials (Holmans interview). The team secured political input through the fact that Heiser reported directly to Peter Shore (T Heiser interview, March 2007). Committee scrutiny provided an opportunity for the Treasury and others to influence the final document; at this stage the Treasury was pressing for provisions that would cut public expenditure on local authority housing, and for reassurances that the proposed subsidy system would permit real increases in rents but the DoE team were relieved that their draft emerged almost unscathed (Holmans interview).

From the point of view of the civil servants involved it was important to be seen to have completed a good professional job. The decision to publish the technical volumes reflects this desire to have something to show for all the effort that had been expended over so long a period. Looking back, Sir Terry Heiser recalls that they were very pleased with the green paper when it finally emerged (interview 2007).

To sum up the conduct of the review, an enormous amount of intellectual effort was put into the production of papers on which reform could be built, but there was a critical lack of political leadership. There was also a good deal of tension and disagreement both within the DoE (chiefly between the professional economists and the permanent civil servants), and between the Department and the Treasury and the CPRS. 


\section{Explaining the housing Finance/Policy Review}

The existing literature does not pay much attention to the question of why the review came out as it did (Holmans, 1991). At one level it seems reasonable to conclude that the broadening of the finance review into a policy review was a tactical response to the failure to agree a reformed housing finance system; widening the scope softened the focus on finance. Even so, Merrett (1979: 268) was quite right to argue that it amounted to 'merely some elements' of a housing policy. On the central problem of housing finance, one possibility is that it was, as the green paper implied, simply not possible to find a fair and equitable cross tenure framework for setting rents and distributing assistance. This begs the question of whether it was theoretically impossible, or just impossible to find a system that enough people could agree on. A paper prepared for the Secretary of State referred to local authority housing and owner occupation as 'like apples and oranges' (TNA, HLG 118/2563, January 1977), suggesting that a cross tenure system was impossible in principle. However, it is apparent that there were rival versions of equitable models produced by the review team and the CPRS, and that therefore the explanation is that it was a question of failure to agree.

One possibility is that the outcome of the review can be explained in terms of personalities. Peter Shore has often been seen as adopting a conservative stance on housing. He certainly steered the green paper towards a more enthusiastic position on home ownership, and away from reform of MITR, even at the higher rate (although this remained in doubt until late in the process (Holmans interview)). However, Anthony Crosland also influenced the process by initially opting for a thorough review, when it might have been argued that the time to push through reform was in the wake of the defeat and repeal of the 1972 Act. As Sir Terry Heiser now points out, the review is a good example of the dilemma often faced by policy makers - whether to go for a quick solution when the time is right, but risk getting the wrong policy, or wait for a well researched policy that might be politically unfeasible by the time it appears. The problem in this case was that Labour came into office in February 1974, following a snap election, with no worked-out policy beyond repealing the contentious parts of the 1972 Act. So in a sense there was no choice but to wait. Nevertheless, Crosland's way of working was mentioned by several interviewees as a factor that extended the whole process and contributed to the lack of political leadership. None of those interviewed for this article felt that Crosland's departure from the DoE made much difference to the final outcome, although he might have pushed for rather more adventurous reforms. The key personalities do not seem to be the main reason for the conservative proposals in the green paper.

A second line of investigation concerns the possibility that the outcome was influenced by the tension between strategic vision and practical politics. Had Crosland been more engaged during 1975 it is possible that the different approaches of the temporary and permanent civil servants within the DoE might have been resolved. Intra- and inter-departmental tension was a factor, and as has been shown above, relations between the DoE on the one hand and Treasury and CPRS on the other, were not conducive to constructive policy making. This suggests that one way of understanding the green paper is to see it as a triumph of practicality over principle and theoretical correctness. Thus, while the thinkers were arguing for a set of principles to be agreed and made explicit, senior DoE civil servants were seeking a solution that they could make work.

Two key concerns for the DoE were the difficulty of implementing a policy that imposed increased costs across the board, and the need to make sure any proposals would be agreeable to the local authorities. On the first point, the DoE did not 
necessarily accept the claim that households in general should pay more their housing. What the market economists saw as inflated demand and over-consumption was seen by the DoE as genuine improvements in the quality of housing (Holmans interview). It is also important to remember the context of the time: inflation was running at record levels throughout the review process, and keeping local authority rent increases under control was a part of anti-inflation policy and incomes policy (including the so-called social contract between the government and the unions). Another consideration was that Crosland had made it clear that he wanted no proposals that would extend the amount of means testing (Holmans interview), and any scheme that raised the general level of rents would be likely to do just that.

House prices were not subject to control of course, but government could avoid policy decisions that would raise the costs of borrowing incurred by home owners. MITR can be seen as partly capitalised and therefore offering little real benefit to consumers (as opposed to land owners), but in the context of the mid-1970s when interest rates were above 11 per cent then MITR was providing valuable support. To remove it, or to seek to introduce a new tax on imputed rental income, would have been politically very difficult in the circumstances, whatever the theoretical arguments for doing so.

In relation to the local authorities, the DoE had a culture that emphasised negotiation and co-operation with local government (Wilkes, 1987), and in the wake of the bitter conflict engendered by the Housing Finance Act, 1972, the Department was not looking for further difficulty. Any system that sought to apply a general set of principles to rent setting across the board would implicitly remove local freedom to set rents. This would have been contentious, especially given that rent setting powers had been so recently returned to local councils. Again, it is important to remember the context of the times and the considerably greater influence of local authorities as compared with the present. This was partly due to the fact that they owned nearly a third of the total housing stock.

A third, and not entirely separate, line is to argue that the Labour Party was incapable of making the sorts of changes that were needed, especially in relation to local authority housing finance. Labour had a long and close association with council housing and was very defensive about it. And for reasons just mentioned, the Party could not easily implement policies that would offend the local authorities. There was a real contrast here between the Labour Party's conciliatory approach to local government and the Conservatives' disregard for the claims of local autonomy in both 1972 and later in 1980. Labour's adherence to certain basic ideas about council housing finance may have been understandable but it was unsustainable. Take for example the Party's commitment to the no-profit rule on housing revenue accounts. This was a well-established principle, which had been overturned by the Conservatives in 1972, but the combined effect of inflation and falling levels of new building, particularly in some localities, meant that it was hard to defend the rule. Labour was more or less compelled by the vehemence of the campaigns waged by tenants and local councillors (many of them Labour voters) to oppose the 1972 Act, but it illustrates how the rough and tumble of party politics can sometimes lead to difficulties. In this case there were aspects of the Act that were worth adopting and/or modifying, but the polarised positions adopted in 1971-4 made it very difficult to recognise any good in it.

A fourth possibility is that it was wider events that made it difficult for the green paper to contain radical reform proposals. This refers to the weak position of the government, struggling with a severe economic crisis, high inflation and a vanishing parliamentary majority. It is arguable that in those trying circumstances reform would have been beyond any government of any political persuasion. It is ironic that the difficult conditions that helped Labour into government in 1974 and which helped to 
precipitate the decision to set up the review also made the implementation of reform a practical impossibility. As already mentioned, inflationary conditions made it difficult to reform both rents policy and MITR, and as Labour's Commons majority melted away in 1976 ministers naturally looked askance at proposals that might threaten even more Labour MPs at an election that could come at any moment. This may well have been the reason that MITR for higher rate tax payers, which had been expected to be removed, was retained at the last minute (Holmans interview).

These four lines of thinking are closely connected and by no means mutually exclusive. Personalities, tensions among different interests, the nature of the Labour Party at that time and wider events swirling around the review all played a part. One thing that emerges from all this is that the application of enormous amounts of intellectual effort by talented and committed people is not always sufficient to guarantee a successful outcome.

\section{Conclusion}

By looking at the process and the context of the time it becomes clear that the green paper was a triumph of the art of the possible over theoretical purity and long term strategy. It was the pragmatists and administrators who had most influence on the final document, not the academic economists who had done so much of the early work. This impression is reinforced by the very similar claims made by two interviewees who were involved in quite different roles, one a political adviser and the other a senior civil servant:

No doubt we should have been braver; but it is doubtful whether we would have got away with much more (Lord Lipsey).

The 1979 subsidy system was as much as we could get away with en route to somewhere better (Sir Terry Heiser).

Both interviewees were clearly articulating a view of policy making as the art of the possible, encapsulated in references to what could be 'got away with'. If that is the view after thirty years of those actually involved, a more detached view is to say that the green paper can now be seen as part of the crisis that was the 1970s, as Britain (and the rest of the world) came to terms with the collapse of the postwar settlement. In housing the period of postwar reconstruction was coming to an end and a new phase was beginning (Harloe, 1995). The transition created tensions, especially within the established system for financing council housing, which was based on supply side subsidies and historic cost pricing. The Labour Party, as the party most closely identified with council housing, was ill-equipped to deal with these tensions, and so to some extent the green paper reflected this situation.

Taking an even longer term view, the green paper can be seen as consistent with the housing market modernisation thesis (Malpass and Murie, 1999), which suggests that council housing was a tenure in transition, and already moving away from being a tenure of choice, still less one of aspiration. In this situation it was difficult to find much support among politicians and the general public for a tenure neutral housing finance system. Arguments for greater fairness between tenures had some theoretical appeal but virtually no support in the world of practical politics.

The game was already up for council housing. The argument for tenure neutrality and cross tenure fairness had been lost, probably under the previous Labour government in the 1960 s. The green paper of 1977 certainly failed to articulate the 
case for greater fairness, displaying instead enthusiasm for policies designed to reinforce the inter-tenure preference gradient among consumers. But it is arguable, therefore, that the housing finance review never stood a chance of achieving the sort of radical reform that Crosland envisaged. Nevertheless, by not even trying to set out and advocate a coherent fairness based housing finance system Labour's green paper left the way open for the subsequent Conservative government to press ahead with policies based on the exact opposite of fairness between tenures. And as Stewart Lansley (1979: 218) predicted, the housing situation in subsequent years did indeed suffer as a consequence.

In terms of what the research tells us about policy making processes today, there are three points to bring out. First, timing is probably more important than the amount of brain power that is brought to bear on a problem. This relates to Sir Terry Heiser's acknowledgement of the dilemma of whether to seize the moment or spend time devising the best solution, and the more general point about the zeitgeist. The housing finance review illustrates the limits of the freedom of any government to make policy that runs counter to the mood and circumstances of the time.

Second, looking at the 1970s review helps to highlight the character of contemporary equivalents: nowadays policy reviews tend to be highly personalised and carried out by named individuals (Barker, 2003, 2004, Hills, 2007, Cave, 2007, Calcutt, 2007) rather than by committees. This raises questions about why reviews have become personalised and distanced from ministers in this way. It also raises the issue of the status of these sorts of reviews in the real policy making process.

Third, this research supports the general conclusion reached by the team evaluating housing policy over the period 1975-2000 (ODPM, 2005: 4), namely that "policies are most successful when they follow the grain of economic and social change, and least successful when they do not'. The Labour government was simply out of step with the wider political climate of the times, and it is arguable, with hindsight, that the really important policy work in the mid to late 1970s was going on elsewhere, in the Conservative Party, not in the policy review at all. The Conservatives' promotion of the right to buy (not evidence-based, not steeped in technical reviews but largely propelled by raw political instinct and opportunism) was more in tune with the zeitgeist. It was their work on developing the right to buy, on promoting home ownership more generally, and on the abandonment of any attempt to develop tenure neutral housing policy that had greater long term impact. The lesson might therefore be that even apparently independent policy reviews today are to some extent constrained by the known preferences of ministers (see also Holmans, 1991) and that we should look beyond formal governmental policy processes.

*Correspondence Address: Peter Malpass, Faculty of the Built Environment, University of the West of England, Bristol BS16 1QY. Email: Peter.malpass@uwe.ac.uk.

\section{References}

Barker, K. (2003) Review of Housing Supply: securing our future needs. An interim report. London: Treasury and ODPM.

- (2004) Review of Housing Supply: delivering stability: securing our housing needs, Final report. London: HMSO.

Boleat, M. (1982) The Building Society Industry. London: Allen and Unwin.

Cairncross, A. (1992) The British Economy Since 1945. Oxford: Basil Blackwell.

Calcutt, J. (2007) The Review of Housebuilding Delivery - the Callcutt Review. London: CLG. 
Cave, M. (2007) Every Tenant Matters: A review of social housing regulation. London: CLG.

DoE (Department of the Environment) (1971) Fair Deal for Housing. London: HMSO. Cmnd 4728.

(1977) Housing Policy: a consultative document. London: HMSO. Cmnd 6851), plus Housing policy Technical Volumes I, II and III. London: HMSO.

Foster, C. (2005) British Government in Crisis. Oxford: Hart.

Ginsburg, N (1999) 'Housing' in: Page, R and Silburn, R (eds) British Social Welfare in the Twentieth Century. Basingstoke: Macmillan.

Harloe, M. (1978) 'The Green Paper on housing policy' in: Brown, M and Baldwin, S (eds) The Year Book of Social Policy in Britain 1977. London: Routledge and Kegan Paul.

(1995) The People's Home? Social Rented Housing in Europe and America. Oxford: Blackwell.

Hills, J. (2007) Ends and Means: the future roles of social housing in England. London: LSE.

Holmans, A. (1991) The 1977 National Housing Policy Review in Retrospect. Housing Studies, 6, 3, 206-219.

Kilroy, B. (1978) Housing Finance - organic reform? London: Labour Economic Finance and Taxation Association.

- (1984) Housing Finance - organic reform? London: Labour Economic finance and Taxation Association.

Lansley, S. (1979) Housing and Public Policy. London: Croom Helm.

Lowe, R. (1993) The Welfare State in Britain Since 1945. Basingstoke: Macmillan.

Malpass, P. (1990) Reshaping Housing Policy: subsidies, rents and residualisation. London: Routledge.

(2005) Housing and the Welfare State. Basingstoke: Palgrave.

Malpass, P. and Murie, M. (1982) Housing Policy and Practice. Basingstoke: Macmillan.

- (1999) Housing Policy and Practice. Basingstoke: Macmillan, 5th edition.

Merrett, S. (1979) State Housing in Britain. London: Routledge and Kegan Paul.

ODPM (2005) Lessons from the Past, Challenges for the Future of Housing Policy. London: ODPM.

Parker, R. (1967) The Rents of Council Houses. London: Bell.

Pollard, S. (1983) The Development of the British Economy 1914-1980. London: Arnold, 3th edition.

Wilks, S. (1987) Administrative culture and Policy Making in the Department of the Environment. Public Policy and Administration, 2, 1, 25-41. 